\title{
Towards a theory of technological mismatch: 1 - consumption
}

Citation for published version (APA):

Oude Wansink, M. J. (1995). Towards a theory of technological mismatch: 1 - consumption. MERIT, Maastricht Economic Research Institute on Innovation and Technology. MERIT Research Memoranda No. 015 https://doi.org/10.26481/umamer.1995015

Document status and date:

Published: 01/01/1995

DOI:

10.26481/umamer.1995015

Document Version:

Publisher's PDF, also known as Version of record

\section{Please check the document version of this publication:}

- A submitted manuscript is the version of the article upon submission and before peer-review. There can be important differences between the submitted version and the official published version of record.

People interested in the research are advised to contact the author for the final version of the publication, or visit the DOI to the publisher's website.

- The final author version and the galley proof are versions of the publication after peer review.

- The final published version features the final layout of the paper including the volume, issue and page numbers.

Link to publication

\footnotetext{
General rights rights.

- You may freely distribute the URL identifying the publication in the public portal. please follow below link for the End User Agreement:

www.umlib.nl/taverne-license

Take down policy

If you believe that this document breaches copyright please contact us at:

repository@maastrichtuniversity.nl

providing details and we will investigate your claim.
}

Copyright and moral rights for the publications made accessible in the public portal are retained by the authors and/or other copyright owners and it is a condition of accessing publications that users recognise and abide by the legal requirements associated with these

- Users may download and print one copy of any publication from the public portal for the purpose of private study or research.

- You may not further distribute the material or use it for any profit-making activity or commercial gain

If the publication is distributed under the terms of Article $25 \mathrm{fa}$ of the Dutch Copyright Act, indicated by the "Taverne" license above, 
Towards a Theory of Technological Mismatch

\section{1 - Consumption}

July 1995

$$
\begin{gathered}
\text { M.J. Oude Wansink } \\
\text { MERIT } \\
\text { P.O. Box } 616 \\
6200 \text { MD Maastricht } \\
\text { Phone (0)43 } 883873 \\
\text { Fax (0)43 } 216518
\end{gathered}
$$

E-Mail M.Oudewansink@AlgEc.RuLimburg.NL 


\title{
Contents
}

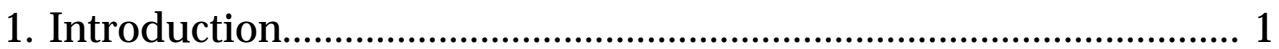

2. Technological Change and Consumption...................................... 2

3. Consumption and Employment.................................................... 8

4. Obsolete Products and Obsolete Skills........................................... 13

5. Summary and Conclusions............................................................... 23

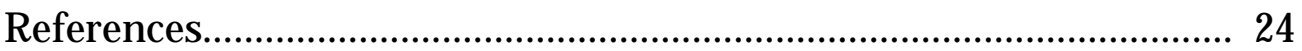

Lables of sectors and product categories in Table 1 and Table 2 of this paper have not been translated in English. The author apologizes for this and offers his help in translating them whenever asked for.

\begin{abstract}
In this paper, the relationship between technological change and employment is analysed using private consumption as a means to do so. Technological change will create new and more consumption opportunities by means of product and process innovation. This results in changes in consumption patterns and budget shares of consumer products. As a consequence of technological change and changing tastes, the production structure will be altered and therefore, changes in (the composition) of employment are inevitable.
\end{abstract}

By using a narrow classification of products as well as occupations, it is possible to analyse the dynamics of adjustment and technological change and their impact on the composition of employment in terms of occupations/skills. Furthermore, obsolescence of products and skills, caused by technological change, can be related to each other by using an input-output framework. The decrease in the (real) consumption of industrial consumer goods has for instance lead to a decrease in the employment of industrial occupations. In addition, scientific/professional occupations seems to have replaced industrial occupations between 1980 and 1990 in the Netherlands. The development of information technology may be a reason for the relative decrease in the employment of commercial skills. 


\section{Introduction}

This paper is part of a $\mathrm{PhD}$ research project on technological change and labour market mismatches. I will try to investigate the impact of technological change on the labour market as channeled through changes in consumer behaviour. Changes in the level of employment as well as changes in the composition of employment in terms of occupations or eduactional backgrounds of workers, caused by technological progress, has thus far mainly been analysed by investigating changes in production structures (Cooper and Clark [1982], Freeman and Soete [1987]). Much attention has also been paid to changes in required skills caused by changes in production processes (Howell and Wolff [1991], Bosworth et al. [1992]).

Another type of analysis stresses the importance of organisational changes for the relation between technological change and labour (Damanpour [1991]). Necessary changes in the organisational structure of the firm, due to innovation, require the adjustment of employment to a new situation. These adjustment processes consist of training programmes for employees and the acquisition of knowledge from outside. Technology may be combined with different organisational structures, but the choice upon such a structure is also a choice upon the composition of jobs and skills (De Wit [1990]).

Katsoulacos [1986] describes the effect of process and product innovation on labour demand and supply. His analysis is useful for investigating the relation between technological change and the labour market, because he recognizes the effect of improvements in processes and products on consumer behaviour. In addition, he also incorporates the effect of sector-specific technical change in a general equilibrium model. Both consumer behaviour and sector-specific technical change are crucial for a good understanding of technological change in the short run.

The relation between technological change the labour market can be investigated by looking more close at the (economic) development of individual products. In the next section, I will start by describing the relation between technological progress and consumer behaviour. In section 3, consumption and labour will be related to each other. Both the analysis in section 2 and 3 will be used to describe in section 4 the economic consequences of the obsolescence of products and skills. Section 5 contains a summary with the main conclusions. 


\section{Technological Change and Consumption}

Once technological change can be divided between product innovation and process innovation, the relation between technological change and consumer behaviour can be divided too. Product innovation is expected to increase the welfare of consumers because they can choose between more products. The effect of process innovation on consumption is expected to be ambiguous: process innovation can be labour saving which causes unemployment and lower levels of consumption, but it can also result in a lower product price and higher levels of consumption. The assumption of utility maximizing consumers in an economic environment without technological change is sufficient to assume next that consumers will not change their behaviour in a situation of equilibrium (steady state). On average, consumers will choose the same combination of products in every period.

In the case of process innovation, the price of a product will fall relative to other products, real income will rise and one of the following reactions of consumers can be expected:

- the decreased price level causes consumers to increase their purchases of the product in such a way, that the level of sales of the product remains constant. Other consumer products have not been crowded out or substituted as a consequence of the innovation (neutrality);

- the decreased price level causes consumers to increase their purchases of the product in such a way, that the level of sales of the product increases. Other consumer products have been crowded out or substituted as a consequence of the innovation (substitution);

- the decreased price level causes consumers to increase, decrease or keep constant their purchases of the product in such a way, that the level of sales of the product decreases. The level of sales of other consumer products must have been increased as a consequence of the innovation (complementarity).

By analysing the effect of process innovation on consumption, the employment effect of process innovation has to be taken into account. There are two employment effects of process innovation. First, this type of innovation can be labour saving, causing an increase in unemployment and a decrease in the aggregate level of consumption. Second, process innovation can result in a lower consumption price level, causing labour supply to increase when utility from consumption increases relative to disutility from working (Katsoulacos [1986]). 
The effect of the latter on the level of consumption is not clear, because much depends on the level of consumption before and after increasing labour supply (enterring the labour market).

Finally, changes in price levels due to process innovation have to be seperated from other price changes. The consumption effect of other price changes can be described as:

- imported deflation: the assumption of perfectly competitive markets means that imported deflation must be the result of better production processes used by foreign producers, and can thus be regarded as (imported) technological change. I assume the practice of dumping to be absent;

- factor cost deflation: when production factors are assumed to be heterogeneous, factor cost deflation will be sector-specific, whereas producers of close substitutes experience the same change in costs. A comparison between the consumption of products manufactured in different sectors, in order to conclude about the impact of technological change, should therefore contain a correction for factor cost deflation;

- lower price levels of intermediary input: lower intermediary costs can also be a sector-specific phenomenon and should be treated in the same way as factor cost deflation. However, lower intermediary cost must come from lower prices caused by technological change, imported deflation or factor cost deflation in earlier stages of the production chain, and it can be useful to find the cause of the cost reduction.

In the case of product innovation, the number of products will increase, and any positive level of consumption of the new product will automatically imply crowding out or substitution of other consumer products. As in the case of process innovation, the effect of product innovation on consumption can be described by the reactions of consumers:

- the appearance of a new product does not change the level of consumption of other products relative to each other. Only the absolute consumption levels of other products decrease after innovation (crowding out);

- the appearance of a new product lowers the level of consumption of some products relative to other products. The absolute consumption levels of some products decrease relatively more after innovation (substitution);

- the appearance of a new product increases the level of consumption of some products relative to other products. The absolute consumption level of some products decrease relatively less or even increase after innovation (complementarity). 
Product innovation is expected to have a positive impact on the level of employment, because the production of the new product creates new jobs. This increase in employment is expected to more than outweight the losses of jobs in the production of products that are crowded out or substituted by the new product (Katsoulacos [1986]). Therefore, the level of consumption is expected to increase because of product innovation.

With respect to both process and product innovation, the speed of diffusion (or adoption) of the innovations play an important role. In Figure 1, I have depicted the adoption process of some newly developed consumer durables in the Netherlands between 1978 and 1993.

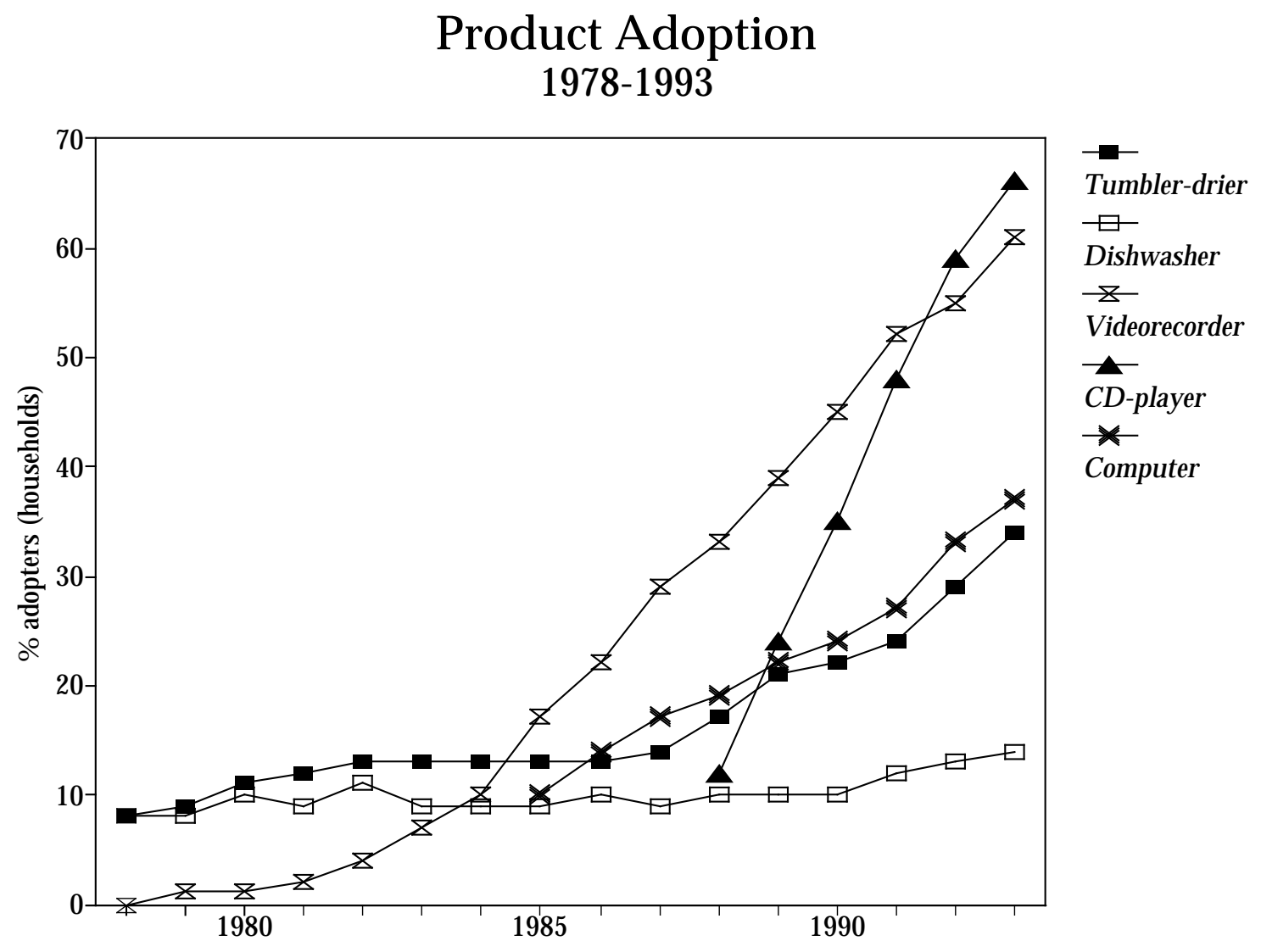

Figure 1

Source: CBS, Budgetonderzoek.

Different products have different diffusion curves and therefore, the impact of product innovation on consumption is not the same for different products. 
The adoption of new product is both dependent on the absolute price of a new product (a CD-player is cheaper than a dishwasher) and the development of the price level of the new product relative to the general price level. The price level of the new product reflect the value of inputs of production factors and intermediary goods. In Figure 2, I have depicted the development of relative prices between 1985 and 1992 for the consumer durables depicted in Figure 1. ${ }^{1}$

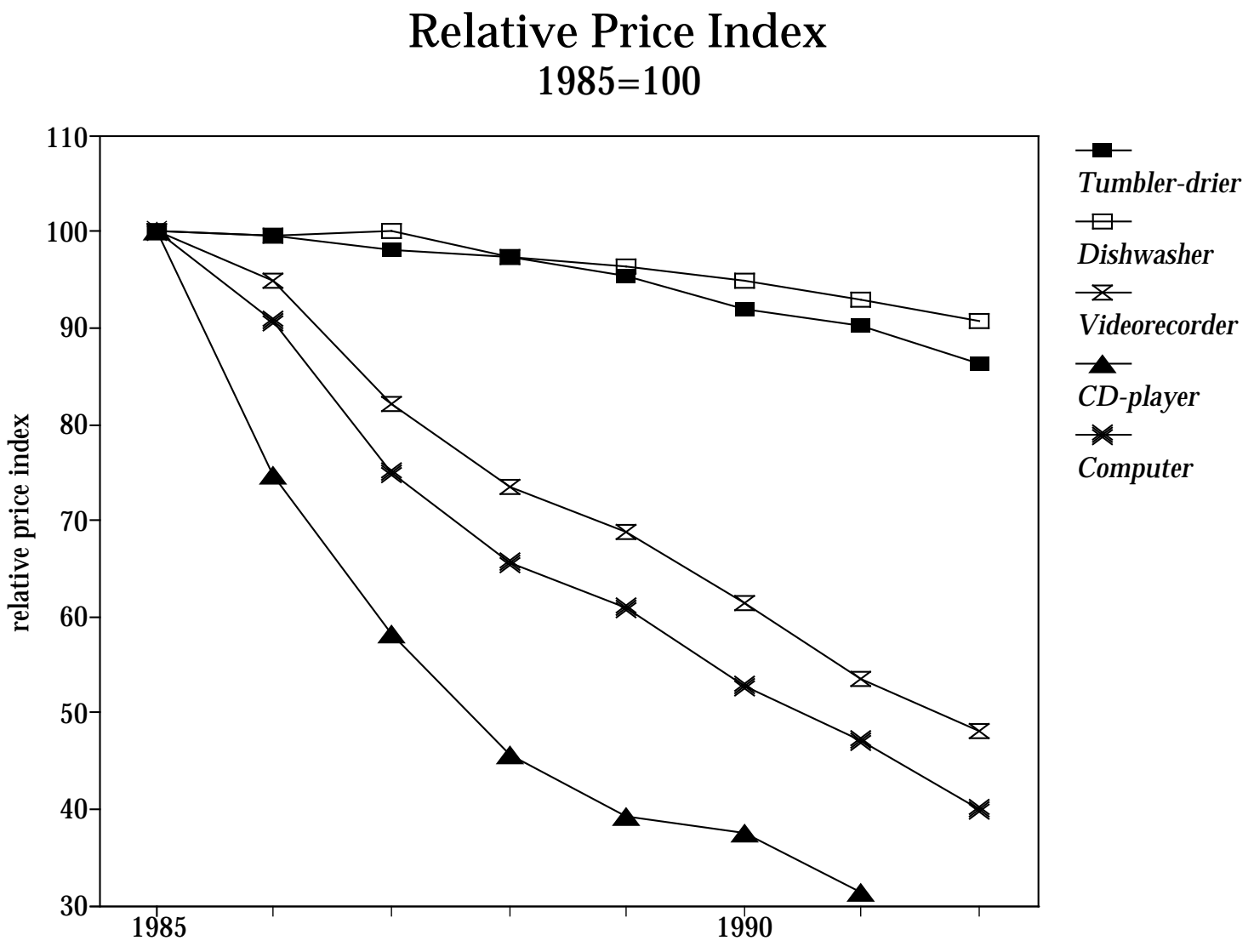

Figure 2

Source: CBS, Bijvoegsel maandstatistiek van de prijzen.

The sharp increase in the diffusion of the CD-player can better be understood when the development of its relative price is taken into account. The 1991 relative price of CD-players amounts to only 30\% of the 1985 relative price, whereas sharp decreases in relative prices can also be observed for computers (60\%) and videorecorders (50\%).

1. The relative price index is calculated by relating the product price index to the consumer price index. 
The relative prices of tumbler-driers and dishwashers have decreased only slightly (about 10\%), but the pattern of diffusion is quite different for these products. The gradual diffusion of computer may be explained by the fact that only privately used computers are accounted for. In most cases, people daily use computers in their jobs, whereas videorecorders and CD-players are typical consumer durables which are only used at home.

The same type of analysis can be done for process innovation. Production processes which are superior to their ancestors are adopted by firms because of comparable reasons as in the case of consumers adopting new products. The cumulative adoption over time is typically S-shaped (like the adoption curve of videorecorders in Figure 1) and has been explained by 2 different theoretical approaches: the epidemic approach and the probit approach (Stoneman [1991]). Without going into detail too much, the epidemic approach explains the S-shape of the diffusion curve by incomplete information. The probit approach explains the typical shape of the curve by assuming a minimum critical value for firms before innovating becomes profitable for them. In the latter case, features of the process innovation itself also play an important role in the diffusion path. In conclusion, the speed of diffusion plays an important role in the relation between technological change and consumption.

Measuring the impact of innovation on consumption is only possible when technology changes the structure of consumption. In order to do so, the classification of products used for analysing the relation is crucial to the outcome. By using a classification with broad product categories, the dynamics of technological change may easily be overlooked because of crowding out and substitution within the same product category. The impact of technological change on consumption can be described by two different effects:

- the substitution effect: new processes and products can be used or consumed instead of other processes and products, as described before;

- the income effect: new processes and products create opportunities to increase real consumption when production costs and output prices decrease over time. An example of an innovation that created an income effect is the introduction of computer-controlled techniques in labour-intensive production processes. Labour employed in such industries can now be used for the production of other products or services, which increases the real consumption opportunities.

Both substitution and income effects of technological change create a new and different structure of consumption as real income increases over time. 
However, the short run effects of innovation, which also affect employment, can only be analysed by using narrow product categories in the analysis. As an illustration, I have depicted the development of expenditure shares of some broad product categories between 1978 and 1991 in Figure 3.

\section{Expenditure Shares \\ 1978-1991}

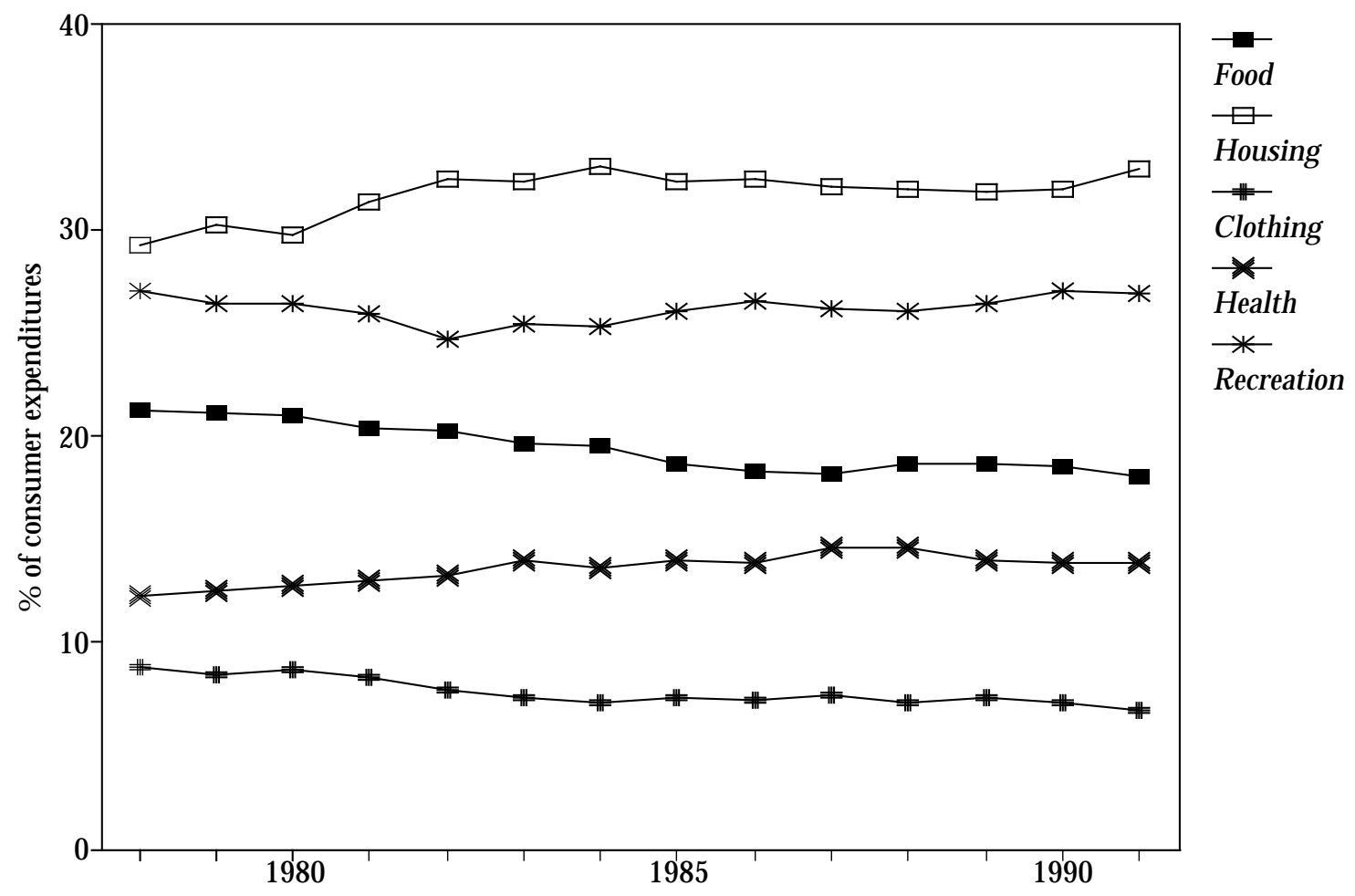

Figure 3

Source: CBS, Budgetonderzoek.

The constant expenditure shares for these broad categories can hardly be used to describe the impact of technological change on consumption. The only conclusion from Figure 3 can be that consumer expenditures for Housing and Health have slightly increased once the basic needs for a living (Food and Clothing) can be paid for. The outlays for Recreation, which includes expenditures on education, have remained fairly constant.

The underlying dynamic structure of products within these broad categories tells the real story about short run technological change and its effect on employment. Even slight changes in the shares in consumption expenditures in Figure 3 represent considerable changes in the level and the composition of employment. This will be described in the next section on consumption and employment. 


\section{Consumption and Employment}

In the previous section, I concluded that narrow product categories are needed to investigate the impact of technological change on consumption and employment. However, data on narrowly defined product categories is hardly available. Since 1988, the Dutch Bureau of Statistics (CBS) has published production statistics for approximately 90 product categories and 60 bussines sectors. In this section, I will use this information to describe the effect of (innovation induced) changes in consumption on employment. Private consumption of sectoral production will be translated in the production of consumer products and employment effects. I am aware of the disadvantages of using such a broad classification, but the data is suitable for calculating employment effects.

Let me start by distinguishing between 5 different destinations of production output:

- intermediary deliveries (ID);

- exports (Exp);

- private consumption (Cgez);

- government (Ovh);

- private investments (Ibdr).

In Table 1, I have put the change in the share (in percentage points) in total sectoral production of these categories for 57 bussines sectors in the Netherlands between 1980 and 1990. From this table, it is clear that the share of private consumption in total output has declined in almost all sectors. In some cases, the decrease amounts to more than $20 \%$ points. The decrease in the private consumption share was in almost all sectors due to an increase in whether the intermediary deliveries share or the exports share.

Because real production has increased in all sectors between 1980 and 1990, total employment has increased in that period with 396,000 full time workers. However, as Table 1 shows, private consumption relatively decreased, which means that I expect private consumption to have had a negative effect on employment between 1980 and 1990. By using an input-output framework, in which I use the abovementioned production data of the CBS, I can both calculate employment effects of private (sectoral) consumption and distinguish between the private consumption of different products. In Figure 4, I have depicted the structure of the input-output framework in terms of the matrices and vectors used in the framework. The framework itself is constructed given constraints of data availability. 


\section{Consumption and Employment}

\section{Change in the relative share in sectoral production of 5 output categories,}

the Netherlands, 1980-1990, $\Delta \%$ points

(ID=intermediary deliveries, Exp=exports, Cgez=private consumption, Ovh=government, Ibdr=private investment)

\begin{tabular}{|c|c|c|c|c|c|}
\hline Sector & ID & Exp & Cgez & Ovh & Ibdr \\
\hline Land-,tuin- en bosbouw & -3.4 & 7.8 & -4.4 & 0.1 & -0.1 \\
\hline Visserij & -6.9 & 15.2 & -8.3 & 0.0 & 0.0 \\
\hline Aardolie- en aardgaswinning & 13.1 & -13.5 & 0.0 & 0.0 & 0.4 \\
\hline Overige delfstoffen & -5.1 & 9.2 & -0.8 & -2.2 & -1.1 \\
\hline Slachterijen en vleeswarenindustrie & 2.9 & 9.8 & -12.6 & 0.0 & 0.0 \\
\hline Zuivel- en melkproduktenindustrie & 5.4 & 1.5 & -7.0 & 0.0 & 0.0 \\
\hline Vis-, groente- en fruitverwerkende industrie & 7.7 & 12.9 & -20.6 & 0.0 & -0.0 \\
\hline Graanverwerkende industrie & -7.8 & 6.1 & 1.7 & 0.0 & 0.0 \\
\hline Suikerindustrie & 6.7 & 5.6 & -12.0 & 0.0 & -0.2 \\
\hline Bloemverwerkende industrie & 4.0 & 6.5 & -10.5 & 0.0 & 0.0 \\
\hline Cacao-,chocolade- en suikerwerkindustrie & 5.1 & -1.2 & -3.9 & 0.0 & 0.0 \\
\hline Margarine-,zetmeel- en overige voedingsmiddelenind. & -5.9 & 16.0 & -10.0 & 0.0 & -0.1 \\
\hline Drankenindustrie & 8.1 & 7.5 & -15.5 & 0.0 & -0.2 \\
\hline Tabakverwerkende industrie & 0.9 & 18.1 & -19.0 & 0.0 & -0.1 \\
\hline Wolindustrie & -21.7 & 22.2 & -0.4 & -0.9 & 0.7 \\
\hline Katoenindustrie & -4.4 & 3.2 & 1.2 & 0.0 & -0.1 \\
\hline Tricot- en kousenindustrie & 4.6 & 17.4 & -22.0 & 0.0 & 0.0 \\
\hline Textielindustrie (overige bedrijven) & -5.0 & 3.2 & -3.7 & -0.9 & 6.3 \\
\hline Kledingindustrie & 22.4 & -17.3 & -6.1 & 0.0 & 1.0 \\
\hline Leder-,schoen- e.a. lederwarenindustrie & -0.3 & 21.2 & -21.2 & 0.0 & 0.3 \\
\hline Hout- en meubelindustrie & -8.4 & 8.8 & -9.6 & -2.6 & 11.9 \\
\hline Papier- en kartonindustrie & -21.6 & 22.6 & -0.9 & 0.0 & -0.2 \\
\hline Papierwaren- en golfkartonindustrie & -5.4 & 7.6 & -2.2 & 0.0 & 0.0 \\
\hline Grafische industrie, uitgeverijen & -0.4 & 2.9 & -2.7 & 0.0 & 0.1 \\
\hline Aardolie-industrie & 7.6 & -14.2 & 6.4 & 0.0 & 0.3 \\
\hline Chemische basisproduktenindustrie & -3.3 & 3.4 & -0.1 & 0.0 & -0.0 \\
\hline Chemische eindproduktenindustrie & -1.0 & 6.2 & -5.1 & 0.0 & -0.0 \\
\hline Rubber- en kunststofverwerkende industrie & -6.3 & 5.4 & -1.7 & -0.4 & 2.9 \\
\hline Bouwmaterialen-, aardewerk- en glasindustrie & -1.6 & 5.0 & -1.6 & -1.8 & -0.1 \\
\hline Basis metaalindustrie & 0.9 & -0.0 & 0.2 & 0.0 & -1.1 \\
\hline Metaalproduktenindustrie & 0.5 & 2.3 & -2.9 & -2.3 & 2.5 \\
\hline Machine-industrie & -2.8 & -1.2 & -0.2 & -1.1 & 5.3 \\
\hline Elektrotechnische industrie & 10.2 & -9.4 & -3.6 & -1.6 & 4.5 \\
\hline Auto-industrie & -5.3 & 14.9 & -1.3 & -0.2 & -8.1 \\
\hline Transportmiddelenindustrie (overige bedrijven) & 2.1 & -5.6 & -3.8 & -0.7 & 8.0 \\
\hline Instrumenten-,optische en overige industrie & 7.4 & -13.0 & 3.6 & -0.8 & 2.8 \\
\hline Elektriciteitsbedrijven & 11.0 & -0.9 & -10.3 & 0.0 & 0.2 \\
\hline Gasdistributiebedrijven & 2.9 & 0.0 & -3.7 & 0.0 & 0.8 \\
\hline Waterleidingsbedrijven & -5.1 & 0.0 & 4.6 & 0.0 & 0.5 \\
\hline Bouwnijverheid- en installatiebedrijven & 4.6 & -0.4 & 0.0 & -12.4 & 8.2 \\
\hline Groothandel en detailhandel & 4.3 & 4.3 & -8.1 & -0.0 & -0.4 \\
\hline Hotels,restaurants,cafe's e.d. & 13.9 & 0.0 & -13.9 & 0.0 & 0.0 \\
\hline Reparatiebedrijven voor gebruiksgoederen & -1.0 & 0.1 & 0.9 & 0.0 & 0.0 \\
\hline Zee- en luchtvaart & -0.5 & -3.4 & 4.1 & 0.0 & -0.2 \\
\hline Overige transport- en opslagbedrijven & -18.5 & 11.7 & 6.9 & 0.0 & -0.1 \\
\hline Communicatiebedrijven & -0.7 & 1.3 & -1.5 & 0.0 & 0.9 \\
\hline Bankwezen & 26.5 & -3.5 & -23.0 & 0.0 & 0.0 \\
\hline Verzekeringswezen & -6.8 & 3.9 & 2.9 & 0.0 & 0.0 \\
\hline Woningbezit & 19.0 & 0.0 & -19.0 & 0.0 & 0.0 \\
\hline Zakelijke dienstverleningen & 13.4 & 2.1 & -2.6 & -1.2 & -11.7 \\
\hline Overheid, burgerlijk & 6.6 & 0.0 & 2.1 & -10.8 & 2.1 \\
\hline Overheid, militair & -0.6 & -0.2 & -0.5 & 1.3 & 0.0 \\
\hline Overheid, openbaar en bijzonder gesubs. onderwijs & 4.8 & 0.1 & 0.8 & -5.7 & 0.0 \\
\hline Maatschappelijke dienstverlening e.d. & -3.3 & -2.8 & 2.4 & 3.7 & 0.0 \\
\hline Gezondheids- en veterinaire diensten & -1.5 & 0.0 & 0.5 & 1.0 & 0.0 \\
\hline Cultuur, sport en recreatie & 2.2 & -0.2 & -10.1 & 8.1 & 0.0 \\
\hline Overige dienstverlenende bedrijven & 14.9 & 0.0 & -27.5 & 12.5 & 0.1 \\
\hline
\end{tabular}

Table 1

Source: CBS, De produktiestructuur van de Nederlandse volkshuishouding 


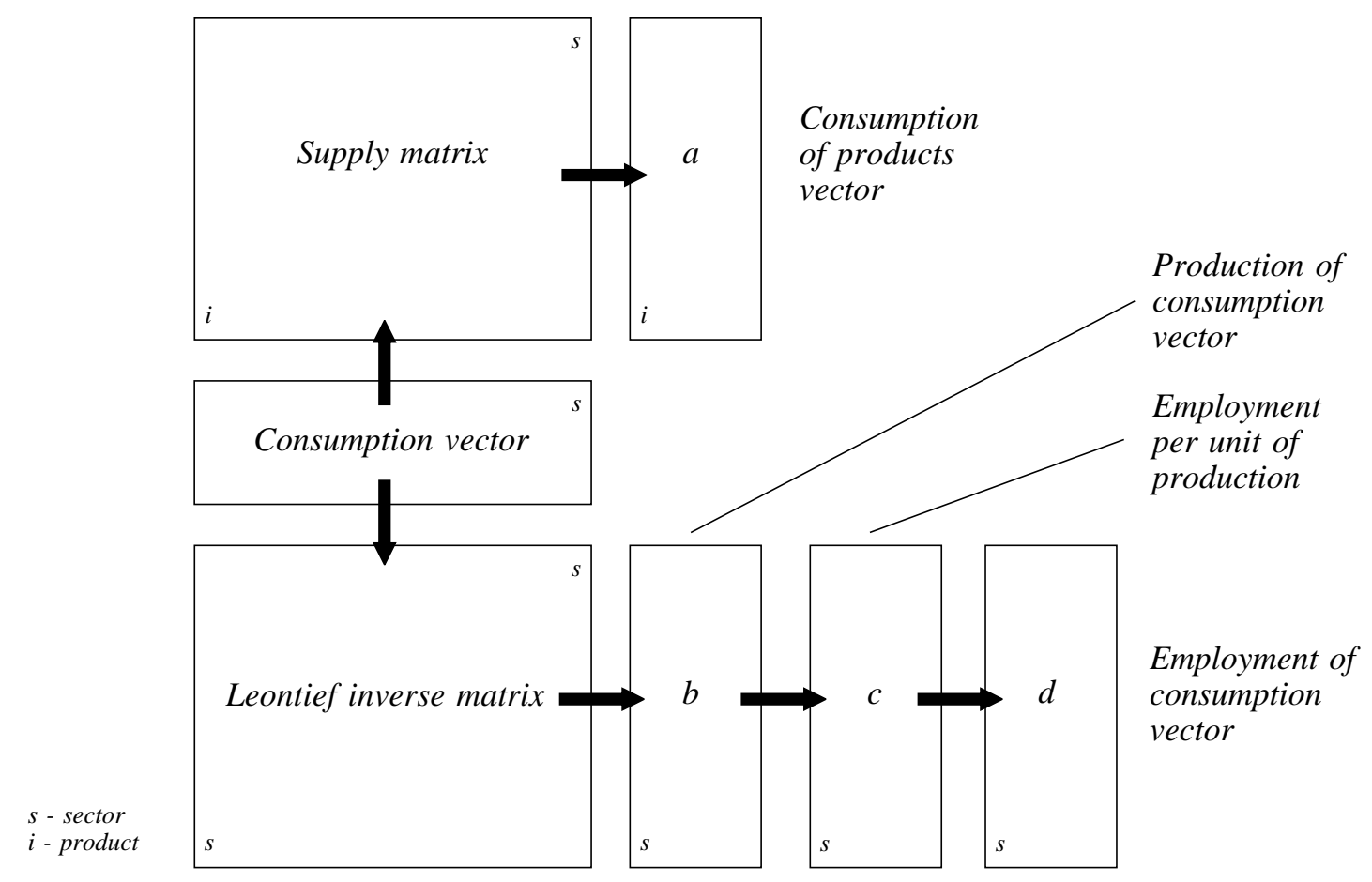

Figure 4

The Input-Output Framework on Consumption and Employment

By using $s$ for sectors and $i$ for consumer products, a supply matrix can be used in order to translate sectoral consumption in consumption of consumer products. The supply matrix contains the supply of different products by different sectors, which is the best approximation of the sectoral production structure in terms of products. The (sectoral) consumption vector and the supply matrix therefore define the consumption of products vector (a) in Figure 4.

On the bottom side of the figure, the consumption vector is translated into sectoral production of consumption (b) by using a Leontief inverse matrix. The latter matrix can be calculated with an input-output table. ${ }^{2}$ Note that, by using the Leontief inverse matrix, I also count for indirect production caused by private consumption. Finally, the production vector (b) can be translated into the employment of consumption vector (d) by using the employment per unit of production vector (c). The framework now allows to compute the effect of private consumption in vector (a) on the accompanying employment structure as given in vector (d). This is illustrated in Table 2.

2. See Miller and Blair (1985) for a description of input-output techniques. 
Direct, Indirect and Total Employment Effects of $f 1 \mathrm{mln}$ Consumption, the Netherlands, 1980 and 1990, full time workers

(Dir=direct employment, Ind=indirect employment, Tot=total employment)

\begin{tabular}{|c|c|c|c|c|c|c|c|c|c|c|c|}
\hline \multirow{2}{*}{\multicolumn{2}{|c|}{ Produkt groep }} & \multicolumn{3}{|c|}{1990} & \multicolumn{3}{|c|}{1980} & \multicolumn{4}{|c|}{$1980-1990$} \\
\hline & & Dir & Ind & Tot & Dir & Ind & Tot & $\Delta$ Dir & $\Delta \operatorname{Ind}$ & $\Delta$ Tot & $\Delta \%$ \\
\hline 1 & Vee & 1.92 & 0.68 & 2.60 & 3.18 & 1.21 & 4.39 & -1.26 & -0.53 & -1.79 & -40 \\
\hline 2 & Bloemen en planten & 0.92 & 0.33 & 1.25 & 1.53 & 0.57 & 2.10 & -0.61 & -0.24 & -0.85 & -40 \\
\hline 3 & Granen & 0.01 & 0.01 & 0.02 & 0.02 & 0.01 & 0.03 & -0.01 & 0.00 & -0.01 & -50 \\
\hline 4 & Overige grondstoffen landbouw en voeding & 0.87 & 0.56 & 1.43 & 1.24 & 1.12 & 2.36 & -0.37 & -0.56 & -0.93 & -30 \\
\hline 5 & Aardappelen, groente en fruit & 0.57 & 0.29 & 0.86 & 1.06 & 0.74 & 1.80 & -0.49 & -0.45 & -0.94 & -46 \\
\hline 6 & Grondstoffen zuivel & 0.13 & 0.54 & 0.67 & 0.18 & 1.04 & 1.22 & -0.05 & -0.50 & -0.55 & -28 \\
\hline 7 & Zuivelprodukten & 0.95 & 4.02 & 4.97 & 1.33 & 7.79 & 9.12 & -0.38 & -3.77 & -4.15 & -29 \\
\hline 8 & Brood en overige bakkerijprodukten & 8.01 & 1.81 & 9.82 & 11.84 & 2.97 & 14.81 & -3.83 & -1.16 & -4.99 & -32 \\
\hline 9 & Vis, vlees, vleeswaren en -conserven & 1.27 & 4.53 & 5.80 & 2.11 & 8.74 & 10.85 & -0.84 & -4.21 & -5.05 & -40 \\
\hline 10 & Overige voedingsmiddelen & 0.81 & 1.15 & 1.96 & 1.14 & 1.94 & 3.08 & -0.33 & -0.79 & -1.12 & -29 \\
\hline 11 & Dranken & 1.05 & 1.06 & 2.11 & 1.78 & 1.53 & 3.31 & -0.73 & -0.47 & -1.20 & -41 \\
\hline 12 & Tabak & 1.09 & 0.77 & 1.86 & 2.40 & 1.36 & 3.76 & -1.31 & -0.59 & -1.90 & -55 \\
\hline 13 & Grondstoffen leder en textiel & 0.52 & 0.19 & 0.71 & 0.79 & 0.28 & 1.07 & -0.27 & -0.09 & -0.36 & -34 \\
\hline 14 & Kleding en textiel & 1.18 & 0.24 & 1.42 & 1.18 & 0.29 & 1.47 & 0.00 & -0.05 & -0.05 & 0 \\
\hline 15 & Lederwaren & 0.49 & 0.15 & 0.64 & 0.80 & 0.24 & 1.04 & -0.31 & -0.09 & -0.40 & -39 \\
\hline 16 & Schoeisel & 0.50 & 0.15 & 0.65 & 0.81 & 0.24 & 1.05 & -0.31 & -0.09 & -0.40 & -38 \\
\hline 17 & Grondstoffen papier & 0.91 & 0.43 & 1.34 & 1.62 & 0.95 & 2.57 & -0.71 & -0.52 & -1.23 & -44 \\
\hline 18 & Papierwaren & 0.43 & 0.20 & 0.63 & 0.78 & 0.43 & 1.21 & -0.35 & -0.23 & -0.58 & -45 \\
\hline 19 & Produkten van drukkerijen en binderijen & 1.44 & 0.91 & 2.35 & 2.23 & 1.52 & 3.75 & -0.79 & -0.61 & -1.40 & -35 \\
\hline 20 & Boeken, kranten, tijdschriften & 0.95 & 0.59 & 1.54 & 1.46 & 1.01 & 2.47 & -0.51 & -0.42 & -0.93 & -35 \\
\hline 21 & Reclamedrukwerk en advertenties & 1.33 & 0.84 & 2.17 & 2.06 & 1.41 & 3.47 & -0.73 & -0.57 & -1.30 & -35 \\
\hline 22 & Bouwmaterialen steen & 1.92 & 0.91 & 2.83 & 3.49 & 1.68 & 5.17 & -1.57 & -0.77 & -2.34 & -45 \\
\hline 23 & Bouwmaterialen hout & 0.96 & 0.20 & 1.16 & 1.47 & 0.51 & 1.98 & -0.51 & -0.31 & -0.82 & -35 \\
\hline 24 & Kunststofartikelen voor bouw en industrie & 0.34 & 0.10 & 0.44 & 0.73 & 0.21 & 0.94 & -0.39 & -0.11 & -0.50 & -53 \\
\hline 25 & Glas intermediair & 0.24 & 0.11 & 0.35 & 0.43 & 0.21 & 0.64 & -0.19 & -0.10 & -0.29 & -44 \\
\hline 26 & Grondstoffen olie en energiedragers & 0.03 & 0.03 & 0.06 & 0.03 & 0.03 & 0.06 & 0.00 & 0.00 & 0.00 & 0 \\
\hline 27 & Overige olieprodukten & 0.01 & 0.01 & 0.02 & 0.01 & 0.00 & 0.01 & 0.00 & 0.01 & 0.01 & 0 \\
\hline 28 & Vloeibare brandstoffen & 0.20 & 0.21 & 0.41 & 0.18 & 0.06 & 0.24 & 0.02 & 0.15 & 0.17 & 11 \\
\hline 29 & Gas & 0.58 & 0.53 & 1.11 & 0.53 & 0.37 & 0.90 & 0.05 & 0.16 & 0.21 & 9 \\
\hline 30 & Elektriciteit & 1.84 & 1.02 & 2.86 & 2.28 & 0.79 & 3.07 & -0.44 & 0.23 & -0.21 & -19 \\
\hline 31 & Water & 3.46 & 1.53 & 4.99 & 5.26 & 1.06 & 6.32 & -1.80 & 0.47 & -1.33 & -34 \\
\hline 32 & Kunstmest & 0.08 & 0.07 & 0.15 & 0.11 & 0.10 & 0.21 & -0.03 & -0.03 & -0.06 & -27 \\
\hline 33 & Kunstharsen, kunststofhalffabrikaten en folie & 0.42 & 0.27 & 0.69 & 0.68 & 0.41 & 1.09 & -0.26 & -0.14 & -0.40 & -38 \\
\hline 34 & Kleur-, reuk- en smaakstoffen & 0.04 & 0.03 & 0.07 & 0.05 & 0.04 & 0.09 & -0.01 & -0.01 & -0.02 & -20 \\
\hline 35 & Overige chemische grondstoffen & 0.47 & 0.40 & 0.87 & 0.64 & 0.56 & 1.20 & -0.17 & -0.16 & -0.33 & -27 \\
\hline 36 & Verfprodukten, drukinkten en plamuur & 0.33 & 0.24 & 0.57 & 0.65 & 0.45 & 1.10 & -0.32 & -0.21 & -0.53 & -49 \\
\hline 37 & Grondstoffen textiel (s+k) en ov. chem. prod. & 0.27 & 0.12 & 0.39 & 0.29 & 0.15 & 0.44 & -0.02 & -0.03 & -0.05 & -7 \\
\hline 38 & Geneesmiddelen en verbandartikelen & 0.40 & 0.30 & 0.70 & 0.80 & 0.55 & 1.35 & -0.40 & -0.25 & -0.65 & -50 \\
\hline 39 & Zeep, was- en reinigingsmiddelen & 0.19 & 0.13 & 0.32 & 0.37 & 0.25 & 0.62 & -0.18 & -0.12 & -0.30 & -49 \\
\hline 40 & Parfumerie en kosmetische produkten & 0.06 & 0.04 & 0.10 & 0.11 & 0.08 & 0.19 & -0.05 & -0.04 & -0.09 & -45 \\
\hline 41 & Chemische bestrijdingsmiddelen e.d. & 0.05 & 0.04 & 0.09 & 0.10 & 0.08 & 0.18 & -0.05 & -0.04 & -0.09 & -50 \\
\hline 42 & Rubber en halffabrikaten van rubber & 0.02 & 0.02 & 0.04 & 0.04 & 0.02 & 0.06 & -0.02 & 0.00 & -0.02 & -50 \\
\hline 43 & Ertsen en overige delfstoffen & 0.00 & 0.00 & 0.00 & 0.00 & 0.01 & 0.01 & 0.00 & -0.01 & -0.01 & - \\
\hline 44 & Overige grondstoffen en halffabrikaten metaal & 0.98 & 0.46 & 1.44 & 1.40 & 0.56 & 1.96 & -0.42 & -0.10 & -0.52 & -30 \\
\hline 45 & Constructiewerk & 1.19 & 0.48 & 1.67 & 2.08 & 0.76 & 2.84 & -0.89 & -0.28 & -1.17 & -43 \\
\hline 46 & Gereedschappen e.d. & 0.06 & 0.02 & 0.08 & 0.10 & 0.03 & 0.13 & -0.04 & -0.01 & -0.05 & -40 \\
\hline 47 & Machines, installaties en onderdelen & 1.04 & 0.40 & 1.44 & 1.69 & 0.59 & 2.28 & -0.65 & -0.19 & -0.84 & -38 \\
\hline 48 & Personen- en vrachtauto's & 0.77 & 0.44 & 1.21 & 1.85 & 0.79 & 2.64 & -1.08 & -0.35 & -1.43 & -58 \\
\hline 49 & Fietsen en motorfietsen & 0.10 & 0.06 & 0.16 & 0.15 & 0.08 & 0.23 & -0.05 & -0.02 & -0.07 & -33 \\
\hline 50 & Onderdelen auto's en tweewielers & 0.17 & 0.09 & 0.26 & 0.39 & 0.17 & 0.56 & -0.22 & -0.08 & -0.30 & -56 \\
\hline 51 & Schepen en vliegtuigen & 1.15 & 0.72 & 1.87 & 1.76 & 0.94 & 2.70 & -0.61 & -0.22 & -0.83 & -35 \\
\hline 52 & Overige transportmiddelen & 0.02 & 0.01 & 0.03 & 0.03 & 0.02 & 0.05 & -0.01 & -0.01 & -0.02 & -33 \\
\hline
\end{tabular}




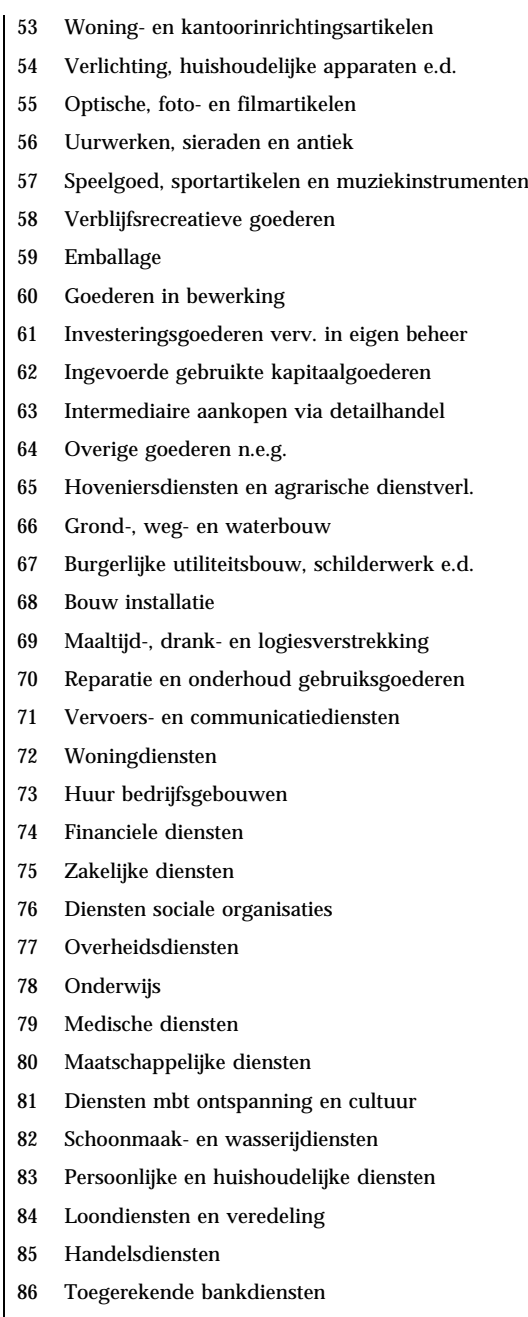

\begin{tabular}{|c|c|c|c|c|c|c|c|c|c|}
\hline 1.05 & 0.30 & 1.35 & 1.76 & 0.63 & 2.39 & -0.71 & -0.33 & -1.04 & -40 \\
\hline 0.55 & 0.18 & 0.73 & 0.74 & 0.18 & 0.92 & -0.19 & -0.00 & -0.19 & -26 \\
\hline 0.22 & 0.14 & 0.36 & 0.38 & 0.24 & 0.62 & -0.16 & -0.10 & -0.26 & -42 \\
\hline 0.02 & 0.01 & 0.03 & 0.03 & 0.01 & 0.04 & -0.01 & -0.00 & -0.01 & -33 \\
\hline 0.14 & 0.05 & 0.19 & 0.17 & 0.10 & 0.27 & -0.03 & -0.05 & -0.08 & -18 \\
\hline 0.05 & 0.02 & 0.07 & 0.08 & 0.04 & 0.12 & -0.03 & -0.02 & -0.05 & -38 \\
\hline 0.72 & 0.30 & 1.02 & 1.37 & 0.63 & 2.00 & -0.65 & -0.33 & -0.98 & -47 \\
\hline 0.47 & 0.29 & 0.76 & 0.72 & 0.37 & 1.09 & -0.25 & -0.08 & -0.33 & -35 \\
\hline 0.07 & 0.02 & 0.09 & 0.09 & 0.03 & 0.12 & -0.02 & -0.01 & -0.03 & -22 \\
\hline 0.00 & 0.00 & 0.00 & 0.00 & 0.00 & 0.00 & 0.00 & 0.00 & 0.00 & \\
\hline 0.00 & 0.00 & 0.00 & 0.00 & 0.00 & 0.00 & 0.00 & 0.00 & 0.00 & \\
\hline 0.23 & 0.08 & 0.31 & 0.42 & 0.15 & 0.57 & -0.19 & -0.07 & -0.26 & -45 \\
\hline 0.35 & 0.13 & 0.48 & 0.58 & 0.22 & 0.80 & -0.23 & -0.09 & -0.32 & -40 \\
\hline 0.93 & 0.57 & 1.50 & 1.47 & 0.94 & 2.41 & -0.54 & -0.37 & -0.91 & -37 \\
\hline 3.02 & 1.86 & 4.88 & 4.78 & 3.05 & 7.83 & -1.76 & -1.19 & -2.95 & -37 \\
\hline 0.84 & 0.50 & 1.34 & 1.32 & 0.80 & 2.12 & -0.48 & -0.30 & -0.78 & -36 \\
\hline 6.64 & 2.13 & 8.77 & 9.04 & 3.52 & 12.56 & -2.40 & -1.39 & -3.79 & -27 \\
\hline 2.82 & 0.51 & 3.33 & 5.14 & 1.01 & 6.15 & -2.32 & -0.50 & -2.82 & -45 \\
\hline 4.53 & 1.40 & 5.93 & 7.10 & 1.22 & 8.32 & -2.57 & 0.18 & -2.39 & -36 \\
\hline 0.46 & 0.66 & 1.12 & 0.52 & 1.17 & 1.69 & -0.06 & -0.51 & -0.57 & -12 \\
\hline 0.10 & 0.10 & 0.20 & 0.12 & 0.17 & 0.29 & -0.02 & -0.07 & -0.09 & -17 \\
\hline 2.81 & 2.05 & 4.86 & 6.54 & 4.23 & 10.77 & -3.73 & -2.18 & -5.91 & -57 \\
\hline 5.65 & 1.50 & 7.15 & 7.71 & 0.93 & 8.64 & -2.06 & 0.57 & -1.49 & -27 \\
\hline 3.28 & 0.47 & 3.75 & 5.24 & 0.34 & 5.58 & -1.96 & 0.13 & -1.83 & -37 \\
\hline 7.20 & 2.12 & 9.32 & 9.54 & 2.67 & 12.21 & -2.34 & -0.55 & -2.89 & -25 \\
\hline 8.30 & 1.35 & 9.65 & 9.96 & 0.99 & 10.95 & -1.66 & 0.36 & -1.30 & -17 \\
\hline 9.82 & 1.34 & 11.16 & 12.87 & 1.81 & 14.68 & -3.05 & -0.47 & -3.52 & -24 \\
\hline 5.70 & 0.83 & 6.53 & 9.12 & 0.61 & 9.73 & -3.42 & 0.22 & -3.20 & -38 \\
\hline 5.24 & 2.69 & 7.93 & 8.59 & 3.11 & 11.70 & -3.35 & -0.42 & -3.77 & -39 \\
\hline 10.60 & 1.30 & 11.90 & 17.32 & 0.99 & 18.31 & -6.72 & 0.31 & -6.41 & -39 \\
\hline 17.43 & 0.25 & 17.68 & 22.61 & 0.19 & 22.80 & -5.18 & 0.06 & -5.12 & -23 \\
\hline 0.25 & 0.10 & 0.35 & 0.39 & 0.15 & 0.54 & -0.14 & -0.05 & -0.19 & -36 \\
\hline 0.50 & 0.11 & 0.61 & 0.72 & 0.19 & 0.91 & -0.22 & -0.08 & -0.30 & -31 \\
\hline 4.09 & 1.35 & 5.44 & 37.51 & 11.03 & 48.54 & -33.42 & -9.68 & -43.10 & -89 \\
\hline
\end{tabular}

Table 2

Source: CBS, De produktiestructuur van de Nederlandse volkshuishouding

In Table 2, the direct, indirect and total employment (full time workers) per $f 1$ mln consumption is presented for 86 product categories for 1980 and 1990. Both direct and indirect employment have decreased between 1980 and 1990 in almost all categories. The total employment per $f 1 \mathrm{mln}$ of consumption has decreased in almost all categories by $30-40 \%$ (last column of Table 2). For example, $f 1 \mathrm{mln}$ consumption of government services (category 77, 'Overheidsdiensten') resulted in the employment of 12,2 full time workers in 1980: 9.5 direct and 2.7 indirect. This number shows a 24 percent decrease between 1980 and 1990 down to 9.3 full time workers (7.2 direct and 2.1 indirect) in 1990. 
In most categories, the relative level of consumption induced direct and indirect employment hardly changed in the 1980-1990 period (for istance in medical services, category 79, 'Medische diensten'), whereas in some categories, relative changes did occur (for instance in transport- and communication services, category 71, 'Vervoers- en communicatiediensten', and in commercial services, category 75, 'Zakelijke diensten').

The numbers in Table 2 represent the decrease in the number of full time workers employed due to consumption. Together with the observed decrease in the share of consumption as reported in Table 1, a decrease in the total level of employment would be expected as caused by consumption. However, the level of (real and nominal) production and income has increased between 1980 and 1990, which means that, in spite of the decrease in employment per unit of consumption, the total level of employment has increased too. However, increases in employment have been mainly the consequence of increases in the level of intermediary deliveries and exports, as illustrated in Table 1.

The next step to extend the input-output framework would be the analysis of compositional employment effects of consumption. By compositional I mean 'occupations' or 'educations'. This extension will be presented in the next section.

\section{Obsolete Products and Obsolete Skills}

Especially the occupational structure of employment and its changes due to technological change have been studied at length in the literature (see for instance Bosworth et al. [1992]). Some occupations or skills are observed to become obsolete because of technological change and the decrease in consumption of some specific, old products. With a decrease in consumption I do not automatically mean that the (nominal) amount of money spent on these products has been decreased. It means that their share in total consumer expenditure has been decreased. In relation to the production of consumer goods, the following cases of skills obsolescence should be distinguished:

- skills, required for the production of a consumer good, become obsolete because of technological change: the consumer good can easily be substituted by other, newer products. This is skills obsolescence due to labour-labour or capitallabour substitution; 
- skills, required for the production of a consumer good, become obsolete because of technological change: the consumer good is still bought, but real earnings out of production decrease over time. In this case, nominal wages may rise or new (completely different) products appear, which makes the share of the good in consumer expenditures good to decrease. This is skills obsolescence due to technological product crowding out.

One should also take into account specific and general technological change. In the case of general technological change, employment of all types of labour in a sector may decrease after innovation. In the case of specific technological change employment of only some labour types will decrease after innovation. Obsolescence of skills should therefore be related to the change in total employment (per sector). Another aspect is the difference between absolute and relative obsolescence. Absolutely obsolete skills are skills that will not be demanded by firms, whereas relatively obsolete skills are skills that are still demanded by firms, but become less important in relation to other skills. Therefore, it is more useful to look at absolute obsolescence over sectors and relative obsolescence within sectors. Absolute obsolescence can easily be associated with the process of substitution described above (a once-and-for-all change), whereas relative obsolescence can be associated with the process of crowding out (a gradual change).

To express skill obsolescence in relation to product obsolescence, the following obsolescence index can be used:

$$
O(o, i)_{t}=\frac{\text { skills obsolescence }}{\text { product obsolescence }}=\frac{N(o, i)_{t}-N(o, i)_{t-1} / N(o, i)_{t-1}}{N(i)_{t}-N(i)_{t-1} / N(i)_{t-1}}
$$

where

$\mathrm{O}(\mathrm{o}, \mathrm{i})=$ obsolescence indicator for skills $o$ due to consumption of product $i$

$\mathrm{N}(\mathrm{o}, \mathrm{i})=$ employment of skills $o$ due to consumption of product $i$

$\mathrm{N}$ (i) = employment due to consumption of product $i$

$\mathrm{t}=$ time index

This index can be obtained by extending the analysis described in Figure 4 . The structure of the extended analysis is depicted in Figure 5. In comparison to Figure 4 , only an extra matrix ('sectoral distribution of occupations') has been put behind the 'employment of consumption' vector (d), which contains the sectoral dimension of the distribution of occupations (skills). The framework now generates the 'occupations vector' which contains consumption induced employment for every occupation. 


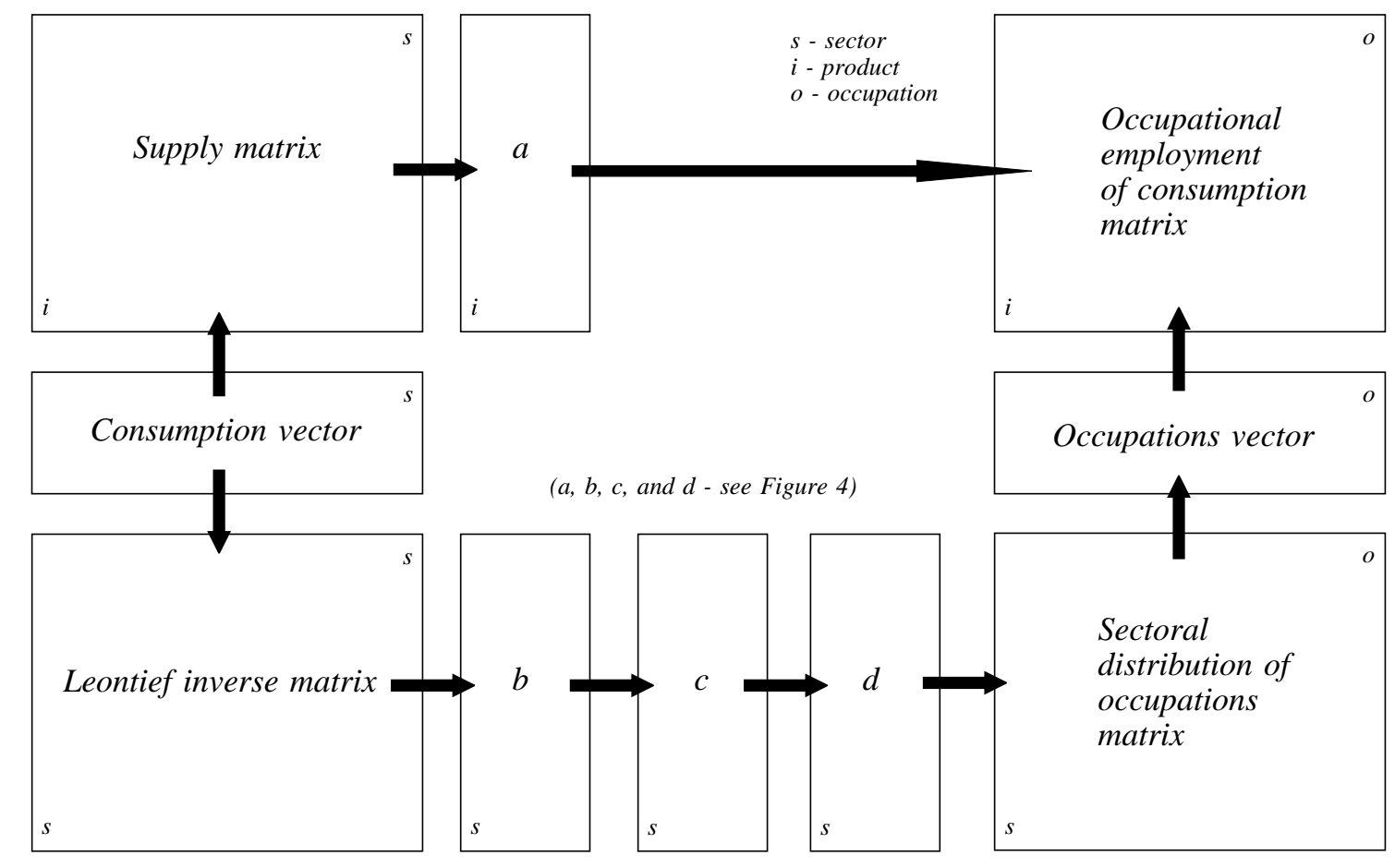

Figure 5

The Extended Input-Output Framework on Consumption and Employment

This means that changes in the consumption of products can be specified in terms of sectoral production and employment effects and changes in the distribution of occupations.In addition, an 'occupational employment of consumption' matrix can be generated, in which the elements represent employment of occupations due to the consumption of products. The elements of this matrix are defined as:

$$
N(o, i)=C(i)\left\{\sum_{s_{1}} \sum_{s_{2}} S(s, i) L\left(s_{1}, s_{2}\right)\right\} \frac{N}{Y}\left(s_{2}\right) N\left(o, s_{2}\right)
$$

where

$\mathrm{N}(\mathrm{o}, \mathrm{i})=$ employment of skill $o$ due to consumption of product $i$

$\mathrm{S}(\mathrm{s}, \mathrm{i})=$ production share of sector $s$ in producing product $i$ (supply matrix)

$\mathrm{L}\left(\mathrm{s}_{1}, \mathrm{~s}_{2}\right)=$ leontief inverse matrix element of sector $s_{1}$ (column) and $s_{2}$ (row)

$\mathrm{N} / \mathrm{Y}(\mathrm{s})=$ employment per unit of production in sector $s$

$\mathrm{N}(\mathrm{o}, \mathrm{s})=$ employment share of skill $o$ in sector $s$

(time index $t$ has been omitted) 
One remark should be made before I continue. Not all the elements in the 'occupational employment of consumption' matrix are equally meaningful, because the 'sectoral distribution of occupations' matrix has been calculated by using the most desaggregated occupational distribution known for every sector. This means that in my matrix occupations may be employed in sectors in which they actually are not present at all. This is merely a consequence of the limited availability of micro data. However, because the closest distribution of skills has been used in calculating the data, results can be used for some general conclusions.

I will not present the obsolescence indices for 85 occupations and 86 products. Instead, I will focus on the development of employment of some broad categories of occupations for some specific product groups. In Table 3, I have put the budget shares for some product categories for both 1980 and 1990, as well as an index of the level of real consumption and of the price level of these products for the same period $(1980=100)$. The choice of products is merely based on presenting the results for prodcuts which represent:

- agricultural products (Potatoes, vegetables and fruits, Agricultural services (gardening));

- industrial products (Drinks, Tobacco, Clothes and textiles, Leather products and Shoes);

- energy products/services (Gas, Electricity);

- handmade products (Clockwork, ornament and antiques);

- nongovernment services (Housing services, Financial services, Commercial services);

- government services (Government services);

- quasi-government services (Medical services).

The products mentioned in Table 3 account for almost one third of the consumer budget. Medical services account for more than 10\%, whereas the share of housing services has increased from $8 \%$ up to $14 \%$. It must be mentioned that the number for the budget share has not been corrected for changes in the price level. The housing services price level, for instance, has increased by $50 \%$ between 1980 and 1990 and that, among other reasons, explains the sharp rise in the budget share. The total level of real consumption has been increased between 1980 and 1990, but most of the products in Table 3 have experienced a decrease in their level of real consumption. Only consumption of medicines and most of the services has increased between 1980 and 1990. 
Budget shares and the change in the level of real consumption for 16 product categories, the Netherlands, 1980-1990

\begin{tabular}{|c|c|c|c|c|}
\hline Product Category & $\begin{array}{r}\text { Budget } \\
\text { Share } \\
1980 \\
(\%)\end{array}$ & $\begin{array}{r}\text { Budget } \\
\text { Share } \\
1990 \\
(\%)\end{array}$ & $\begin{array}{r}\text { Consumption } \\
\text { Index } \\
1990 \\
(1980=100)\end{array}$ & $\begin{array}{r}\text { Price } \\
\text { Index } \\
1990 \\
(1980=100)\end{array}$ \\
\hline Potatoes, vegetables and fruits & 0.60 & 0.49 & 79.3 & 119.4 \\
\hline Drinks & 1.22 & 1.06 & 83.9 & 120.2 \\
\hline Tobacco & 1.19 & 1.25 & 81.1 & 150.5 \\
\hline Clothes and textiles & 1.17 & 0.76 & 68.7 & 109.8 \\
\hline Leather products & 0.07 & 0.04 & 71.7 & 108.4 \\
\hline Shoes & 0.19 & 0.14 & 86.3 & 101.5 \\
\hline Gas & 2.19 & 1.96 & 85.5 & 121.6 \\
\hline Electricity & 1.43 & 1.04 & 69.6 & 121.6 \\
\hline Medicines & 0.34 & 0.35 & 113.9 & 105.4 \\
\hline Clockwork, ornament and antiques & 0.15 & 0.10 & 65.8 & 123.1 \\
\hline Agricultural services (gardening) & 0.08 & 0.06 & 69.9 & 123.6 \\
\hline Housing services & 8.15 & 14.38 & 136.7 & 150.0 \\
\hline Financial services & 1.96 & 2.91 & 148.5 & 116.4 \\
\hline Commercial services & 2.15 & 2.06 & 90.2 & 123.6 \\
\hline Government services & 0.23 & 0.55 & 222.3 & 123.6 \\
\hline Medical services & 11.41 & 14.04 & 110.3 & 129.7 \\
\hline
\end{tabular}

Table 3

Source: CBS, De produktiestructuur van de Nederlandse volkshuishouding, Maandstatistiek van de prijzen

Table 3 is presented in order to get an idea about the development of some products before the development of occupations per product category is described. In this description, I will use a broad classification of occupations, consisting of 5 different categories: (1) scientific/professional, (2) administrative, (3) commercial, (4) industrial and (5) others. Among others, mainly agricultural, middlemanagement and horeca (hotels,restaurants,cafés) labour can be found. The development of employment will be discussed using the broader classification of products mentioned on the previous page. 
Agricultural Products

In Figure 6 and Figure 7, I have depicted the shares of occupations in total employment created by the consumption of potatoes, vegetables and fruits and agricultural services (gardening), respectively. Both categories contain agricultural products, which means that the employment share of 'others' (among which the agricultural occupations) is relatively high.

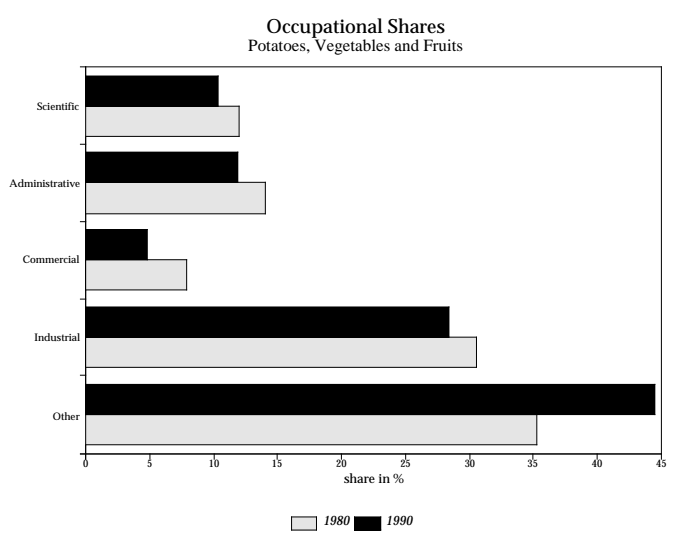

Figure 6

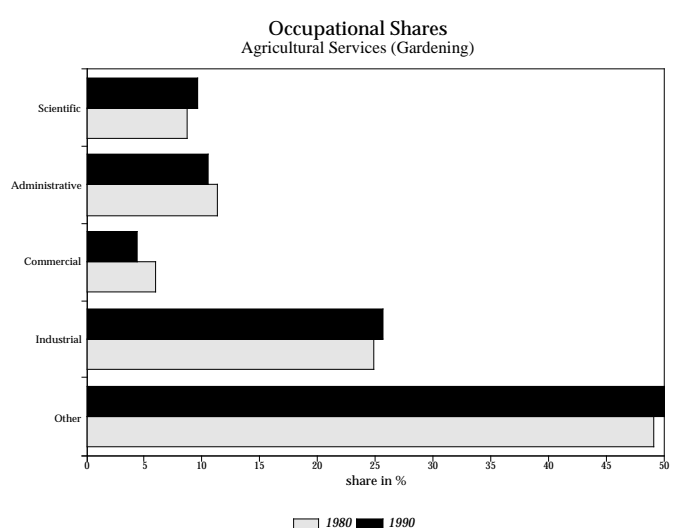

Figure 7

Although the employment shares of both administrative and commercial occupations have decreased in both categories, scientific/professionals and industrial have decreased in potatoes etc. and increased in agricultural services. The changes in the employment shares are small in comparison to the length of the period, which means that no conclusions can be made with respect to relative obsolescence of skills within the product categories. Note, however, that real consumption of these agricultural products has decreased between 1980 and 1990, which means that the products become relatively obsolete.

\section{Industrial Products}

The employment shares of occupational categories for 6 industrial product categories are depicted in the Figures 8 through 13. There is a striking similarity between the figures: the employment shares of scientific and administrative increased while commercial shares decreased. Industrial occupational shares remained constant or decreased, whereas 'others' did only change marginally. Real consumption levels of the industrial products decreased between 1980 and 1990 (see Table 3), which means that commercial and industrial occupations became relatively obsolete. 
Obsolete Products and Obsolete Skills

Occupational Shares

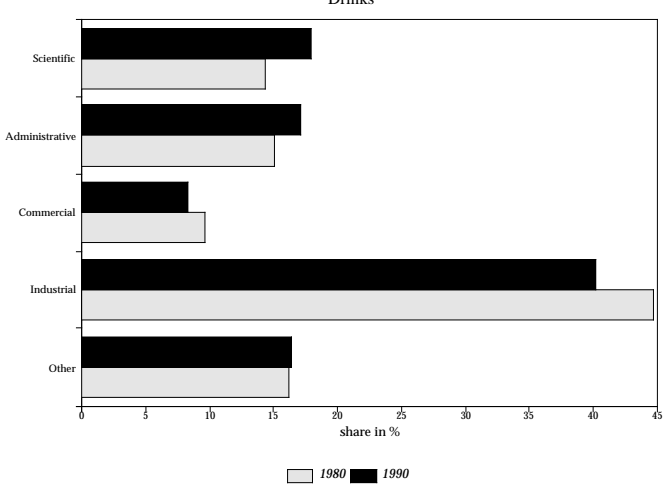

Figure 8

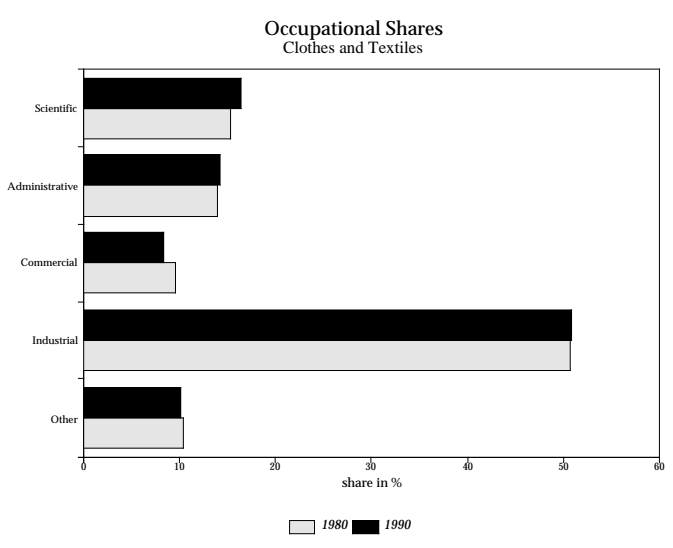

Figure 10

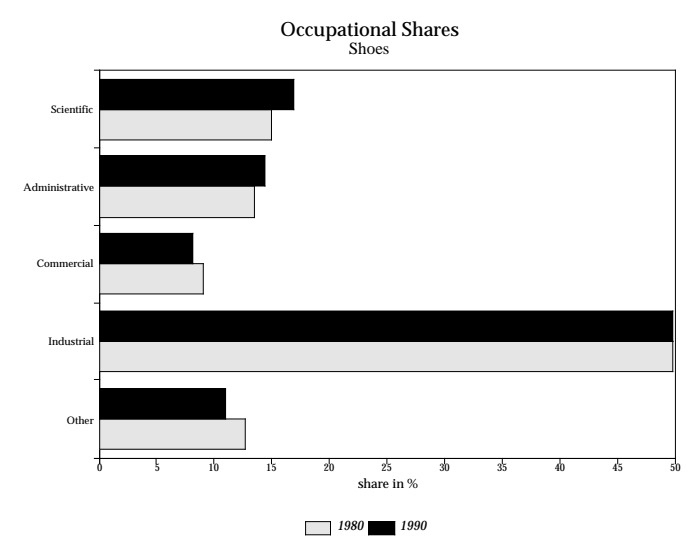

Figure 12

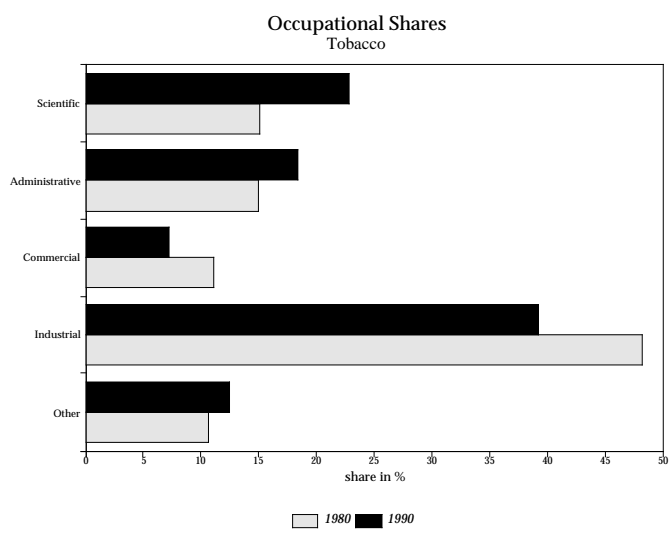

Figure 9

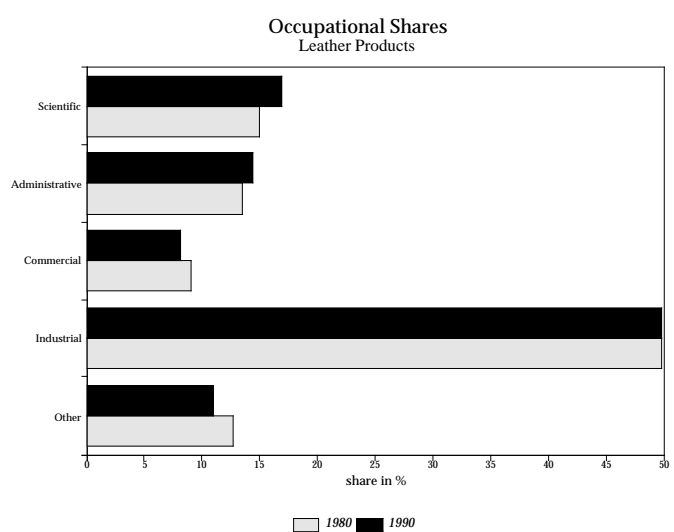

Figure 11

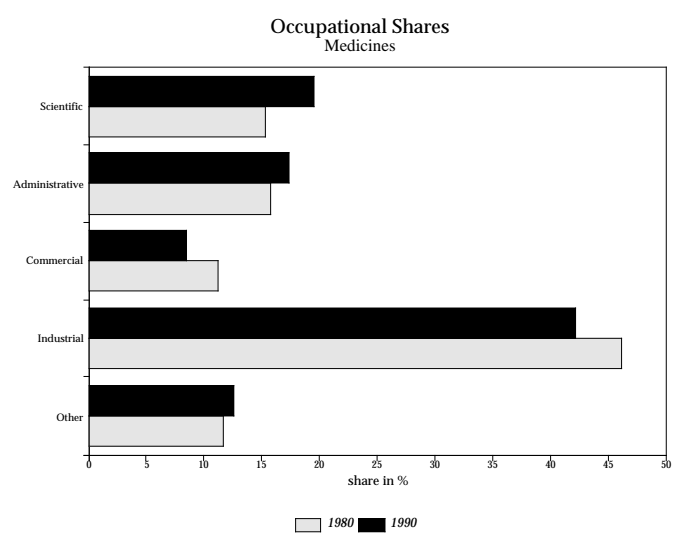

Figure 13 


\section{Energy Products}

The same development can be found for energy products gas and electricity. The share of scientific/professional employment in the production of energy products increased between 1980 and 1990 and the share of industrial occupations decreased. The share of commercial occupations remained merely constant, and the same holds for administrative occupations. It is worthwhile to mention the increase in 'other' occupations in both gas and electricity. This increase refers to middle-management and security and cleaning occupations.

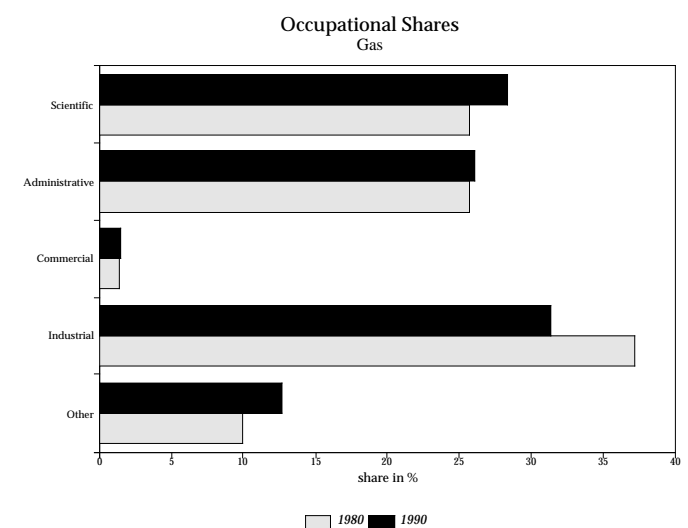

Figure 14

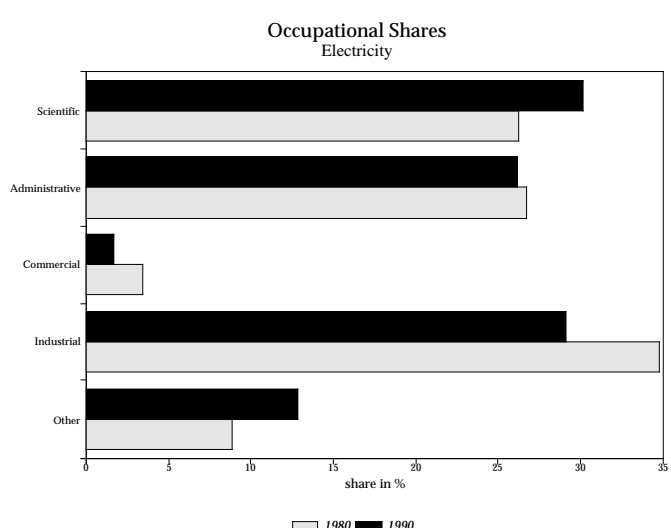

Figure 15

\section{Handmade Products}

In Figure 16, occupational employment shares are depicted for clockwork, ornament and antiques, representing handmade products.

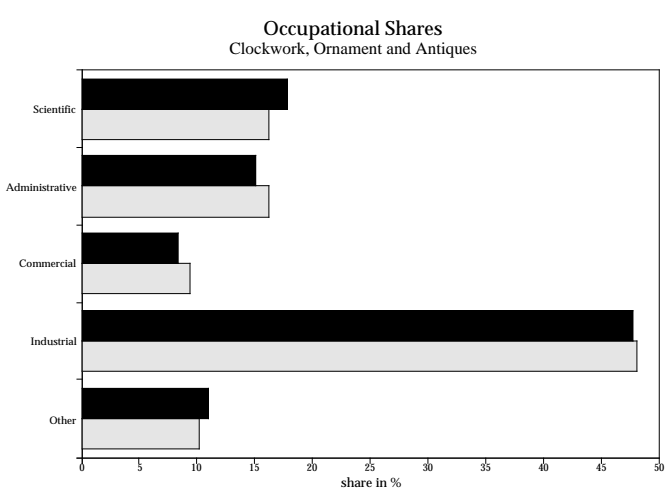

Figure 16 
The employment shares in this sector remained quite constant between 1980 and 1990. As before, however, the scientific/professional category shows an increase.

\section{Nongovernment Services}

Employment shares in the financial (Figure 18) and commercial services (Figure 19) have remained nearly constant between 1980 and 1990. In the case of housing services (Figure 20), scientific/professional, administrative and commercial employment shares increased at the cost of industrial occupational shares.

Notwithstanding the increase in the level of real consumption of housing services, employment for industrial occupations decreased by 26\% between 1980 and 1990 .

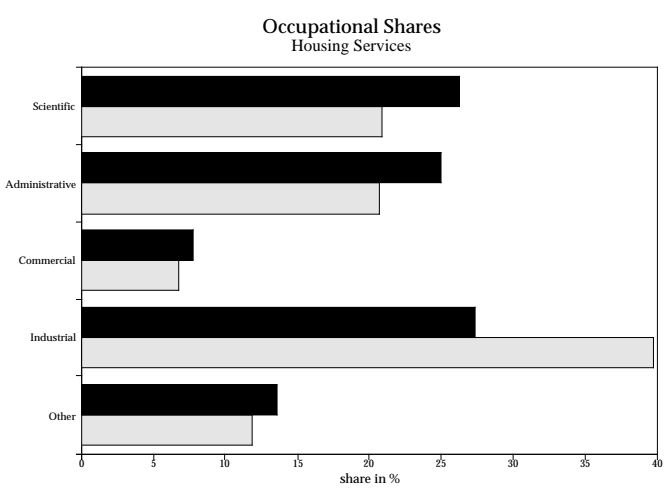

$\square^{1980} \square^{1990}$

Figure 17

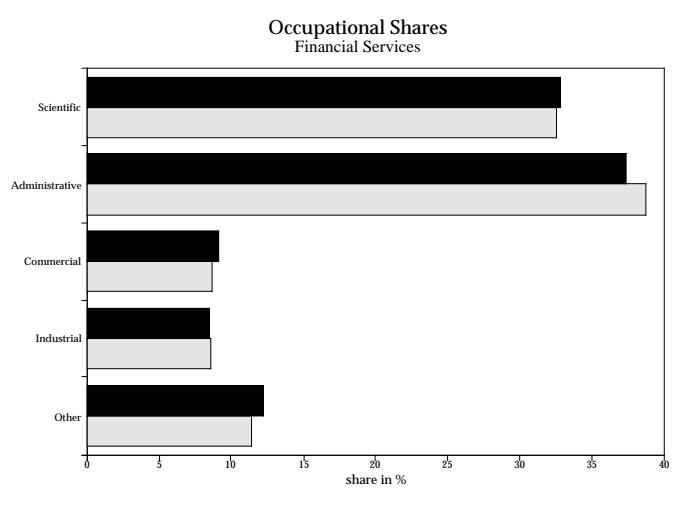

$\square^{1980} \square^{1990}$

Figure 18

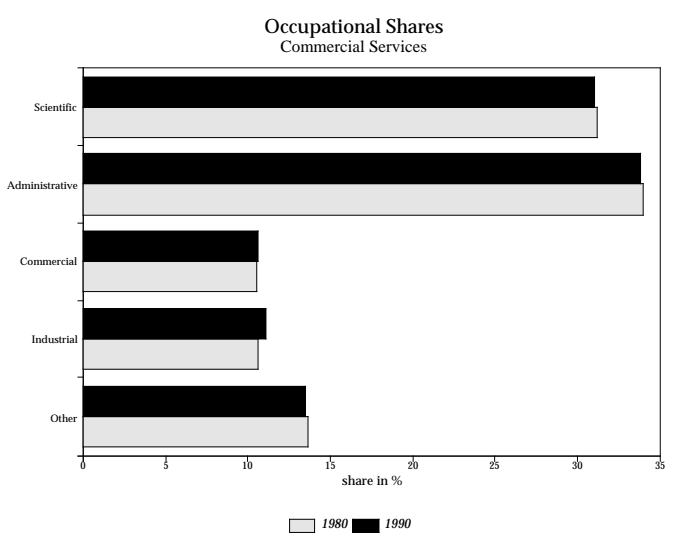

Figure 19 
Government Services

Nothing really changed in the employment distribution of occupations due to the consumption of government services (Figure 20). 'Others' are mainly civil servants and other government officials.

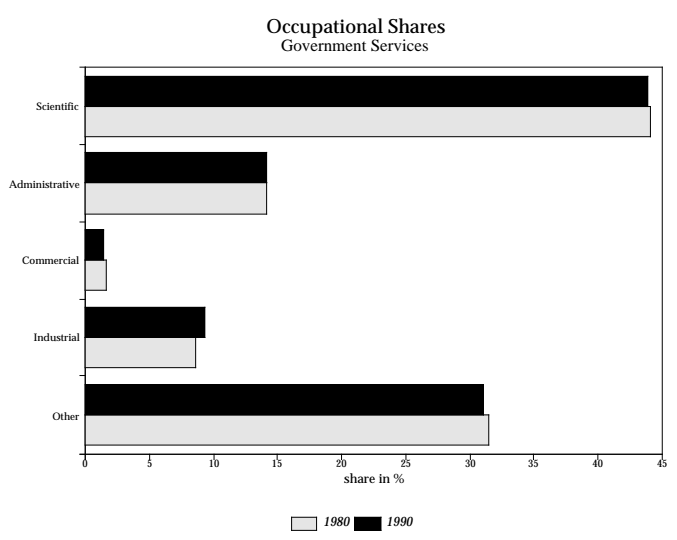

Figure 20

Quasi-Government Services

Quasi-government services (medical services, Figure 21) do not show much variation in the occupational distribution neither. Again, scientific/professional personel increases (slightly!) at the cost of industrial and commercial occupations. 'Others' refers mainly to cooking, caring and cleaning personel in the medical sector.

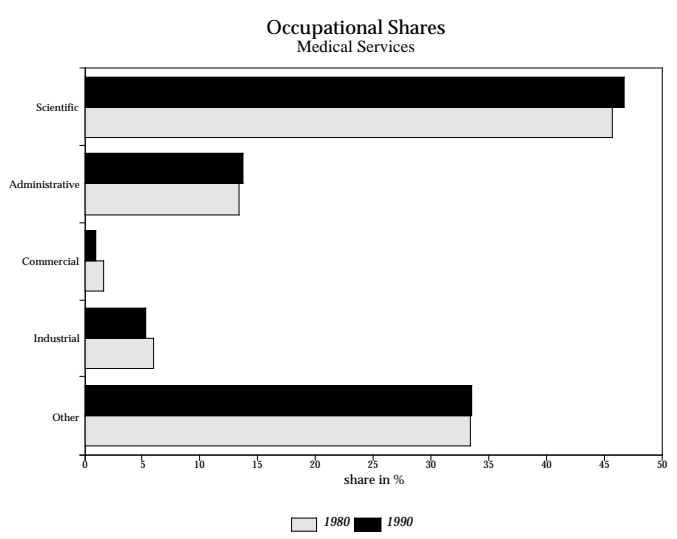

Figure 21 
In conclusion, scientific/professional occupations have relatively increased in employment in almost all product categories, mainly at the cost of industrial occupations. This may be the consequence of technological change, which requires more scientists and professionals to work in flexible working conditions than bluecollar workers in traditional industrial occupations. Furthermore, commercial skills are on their way back too, which may be the result of computerizing the main tasks of commercial personnel (selling, providing information, advertising). The development of information technology plays an important role in explaining this phenomenon. Finally, occupational structures mainly changed between 1980 and 1990 in the production of industrial consumer goods. Occupational shares in employment created by the consumption of services remained nearly constant in almost all cases.

\section{Summary and Conclusions}

This paper describes a first analysis of the relation between technological change and employment via private consumption. Technological change creates new and more consumption opportunities by means of product and process innovation. The change in consumption automatically changes patterns of production, which in turn influences employment and its composition in terms of skills/occupations. The main conclusions of this paper are:

- technological change brings forth new products and processes, which may substitute, crowd out or complement existing products and processes;

- adoption and diffusion processes may not be the same for different products and processes, which means that the effects on consumption patterns may differ too;

- the dynamics of technological change and the accompanying labour market dynamics can only be understood when a narrow classification of products is used to analyse the problem;

- private consumption between 1980 and 1990 relatively decreased in the Netherlands (as related to intermediary output, exports, government outlays and private investments);

- an input-output framework can be used to establish a relationship between the consumption of products and the employment of labour;

- after constructing the distribution of occupations matrix, the input-output framework can establish a relationship between the consumption of products and the employment of occupations. It is now possible to conclude with respect to obsolescence of both products and occupations (skills); 
- the employment shares scientific/professional occupations relatively increased in the Netherlands between 1980 and 1990 at the cost of industrial occupations;

- decreasing employment shares of commercial occupations may be an indication of the development of information technology, computerizing most of the tasks of commercial personel.

The main contribution of the paper consists of the detailed input-output framework that is used to analyse the changes in the composition of employment. In this paper, I still used quite broad categories of products and occupations, but the available Dutch data makes it possible to construct the framework for 58 sectors of business, 86 product categories and 85 occupational categories.

Another interesting elaboration of this paper would be to use available data on the educational backgrounds of workers. The mean level of schooling in the scientific/professional category is higher than in the industrial category. This means that the (relative) decrease in the consumption of some specific products, together with the (relative) increase in the consumption of other products, can explain why structural unemployment consists of mainly low educated workers. I guess that the framework developed in this paper can give the answer.

\section{References}

- Bosworth, D., Dutton, P., Lewis, J. (eds) [1992], Skill Shortages: Causes and Consequences, Avebury, Aldershot.

- Cooper, C.M., Clark J.A. [1982], Employment, Economics and Technology, Harvester Wheatsheaf, Hertfordshire.

- Damanpour, F. [1991], "Organizational Innovation: A Meta-Analysis of Effects of Determinants and Moderators", Academy of Management Journal, vol. 34, no. 3, pp. 555-590.

- Freeman, C., Soete, L. (eds) [1987], Technical Change and Full Employment, Basil Blackwell, Oxford.

- Howell, D.R., Wolff, E.N. [1991], "Trends in the Growth and Distribution of SKills in the U.S. Workplace, 1960-1985", Industrial and Labor Relations Review, vol. 44, no. 3, pp. 486-502.

- Katsoulacos, Y.S. [1986], The Employment Effect of Technical Change, Wheatsheaf Books Ltd., Brighton.

- Miller, R.E., Blair, P.D. [1985], Input-Output Analysis: Foundations and Extensions, Prentice-Hall, Englewood Cliffs. 
- De Wit, R. [1990], "A Review of the Literature on Technological Change and Employment", Macro-Economic and Sectoral Analysis of Future Employment and Training Perspectives in the New Information Technologies in the European Community, MERIT, Maastricht, background report 2. 